\title{
Direct Sales and social relationships in Ponta de Pedras, Pará
}

\section{Vendas diretas e relações sociais em Ponta de Pedras, Pará}

Jessica Chelekis - Ph.D. em Antropologia pela Indiana University. Professora do Department of Sociology and Anthropology da Middle Tennessee State University. E-mail: jchelekis@mtsu.edu

\begin{abstract}
Throughout the Amazon, direct sales companies selling beauty and domestic products - such as Avon and Natura - are extremely popular. Local women make up the direct sales work force, selling perfume, lipstick, and kitchen items to their neighbors and family. This article explores the ways in which global direct sales companies operate in a remote, rural Amazonian community, describing the disjunctures that occur between corporate expectations and reality in rural Amazonia. The main focus of this article is the way in which direct sales works through social relationships, and I argue that direct sales has the potential to both build up social ties as well as break them down.
\end{abstract}

\section{Resumo}

As companhias de vendas diretas que comercializam produtos de beleza e de uso doméstico, tais como a Avon e a Natura, são muito populares na Amazônia. A força de trabalho de revendedores é composta de mulheres locais que vendem perfumes, batons e utensílios domésticos a vizinhas e familiares. Neste artigo, exploram-se as formas em que as companhias globais de venda direta operam em uma comunidade amazônica remota, descrevendo-se a dissociação entre as expectativas das empresas e a realidade na Amazônia rural. O foco principal deste trabalho é a forma em que as vendas diretas funcionam através de relações sociais, e o meu argumento é que as vendas diretas têm um potencial tanto para construir laços sociais como para rompê-los.

\section{Keywords}

Globalization. Direct Sales. Women's Work. Rural Amazonia.

\section{Palavras-chave}

Globalização. Venda Direta. Trabalho de Mulheres. Amazônia Rural. 


\section{INTRODUCTION}

Direct sales is a multi-billion dollar industry that is almost entirely oriented toward women. As of 2009, 76 percent of the 74 million direct sales distributors worldwide are women; in Latin America, the percent of women increases to 86 percent (WFDSA, 2010). ${ }^{1}$ This is not to say that men do not participate in direct sales work or occupy top executive positions in direct sales organizations. But unlike the vast majority of businesses, direct sales companies position themselves as the ideal way for women-especially housewives and mothers-to earn their own money, supplement the household income, go into business for themselves, and be their own boss, all without compromising their fulfillment of domestic and family obligations. In short, direct sales organizations promise to solve a major contradiction of capitalism.

However, direct sales does not always function exactly the way company executives intend for it to work. This article describes the disjunctures that occur between corporate expectations and reality in rural Amazonia. There are two major hitches in the system: one is a problem of infrastructure, in which the actual distribution chain is slowed down due to reliance on river transportation and paper order forms, rather than the faster and more efficient use of roads and the internet. The other issue is ideological. Direct sales corporations depend heavily on local managers to motivate and instruct their distributors in order to keep up sales volumes and increase profits. They do this through monthly meetings with distributors, passing on product information and giving motivational speeches. Sector managers ideally instruct their coordinators to ensure that distributors receive consistent corporate messages in between monthly meetings. As I will explain below, the dissemination of corporate philosophy, product information, and sales incentives for distributors in Ponta de Pedras is at best imperfect, at worst practically non-existent.

The first half of the article focuses on direct sales corporations, moving from a general discussion of the organization of direct sales companies to an examination of the three main companies in Ponta de Pedras. I focus on the paradox in a company philosophy that emphasizes women's independence through work, yet reinforces traditional ideologies of gender roles. The second half discusses the direct sales distributors, the women who sell Avon, Natura, and Hermes in the three study communities. I examine the impact of the direct sales structure on these women's lives and relationships, even as people adapt direct

\footnotetext{
Data is missing for Brazil, but the percent of women direct sales distributors in Argentina and Chile are 94 and 90 , respectively.
} 
sales to fit practices and modes of sociality already in place. I discuss distributors' motives for working in direct sales, which diverge significantly from the motives companies attempt to cultivate in their recruits. Finally, I examine how direct sales works through social relationships. One of the biggest influences on the ideological hitch between corporate expectations and Amazonian reality is the cultural practice of selling on credit. Referring to the literature on the morality of exchange, I argue that direct sales has the potential to both build up social ties as well as break them down.

\section{METHODOLOGY}

In the summers of 2006 and 2007 I conducted preliminary research in Ponta de Pedras, establishing contacts with local elite families, the sales coordinator for Avon, and women working in direct sales. In the summer of 2007 I conducted archival research on the Avon Corporation in Brazil at the Hagley Museum and Library in Delaware. ${ }^{2}$ In the archives I found a scrapbook commemorating the opening of the first Avon factory in Santa Amaro, São Paulo, in 1959. The scrapbook included entries from thirty-six newspaper articles, nine magazine articles, and estimates that a total sixty-three minutes on four different television stations covered the event.

I spent eleven months conducting research in Ponta de Pedras, from October 2008 to August 2009, with a dissertation improvement grant from the National Science Foundation (NSF). The fieldwork consisted primarily of participant-observation, but also included semi-structured interviews, one focus group, and a survey of 100 households, including those with someone working in direct sales, and households in which no one worked in direct sales. Through participant-observation, I collected information about Marajoara lifeand about the kinds of economic and entrepreneurial activities that men and women perform, both in the formal and informal sectors. I lived with three different families in Ponta de Pedras, each in distinct micro-regions: the town of Ponta de Pedras, one of the roadside rural communities called Antonio Vieira, and Rio Fortaleza, a riverine community. I particpated in their daily lives and the lives of neighbors and other community members, and workedclosely with sevendirect sales distributors. I also conductedinterviews with approximately 30 other direct sales distributors.

Hagley is a museum of American businesses, and possesses a library of materials and primary documents associated with the history of American companies. 


\section{DIRECT SALES COMPANIES}

\subsection{Types of direct sales and entrepreneurship}

Due to its loose structure and organization, all direct sales corporations must invest heavily in guiding and shaping their otherwise untrained distributors through meetings, inspirational and "how-to" literature, awards, and discounts; thus, they retain a degree of self-help and religious connections in terms of the values that direct sales corporations promote. Avon and Natura advertisements are replete with self-help messages: as an Avon representative or Natura consultant, you get to be your own boss, set your own hours, gain independence and increased confidence, and most importantly, realize lifelong dreams such as buying a new car or sending your children to school.

Direct sales is a product distribution system in which a distributor (also known as an agent, revendadora, and sometimes even "beauty consultant") formally signs up with a direct sales company to become a licensed salesperson for that organization, paying a small fee for a product starter kit. The distributor sells the company's products to friends, acquaintances, work colleagues, and family members using a product catalog. The customer places an order with the distributor, and the distributor sends in the order to the company, either via postal service or the Internet. Within about fifteen days the product orders are mailed to the distributor, who then delivers the products to each of her clients and receives payment at the time of the delivery. The distributor works on commission, usually receiving between 20-30 percent of her sales.

The literature on women's micro- and small-scale enterprises generally point to a certain kind of logic that differentiates them from the kind of businesses that formal economists routinely study. In describing the ways in which petty capitalism differs from formal businesses, Iris Villalobos Barahona (1995) speaks specifically about women micro- and small-scale enterprises. She defines them as having five features: 1) the main purpose of the enterprise is directed toward satisfying household subsistence needs, 2) the income generated meets at least half of these needs, 3) economic activities are carried out using domestic or simple technology, 4) a simple production process, and 5) local marketing (Barahona 1995: 148). Ethnographies on rural, small-scale farming households often report sporadic, seasonal, or simply micro-/small-scale businesses run from households, or literally “doorstep" businesses (Annis 1986; Gudeman 1992). In describing the ways in which these businesses differ from the logic of more profit-oriented firms that economists are more familiar with, Eversole (2003) explains that micro-/ 
small-scale businesses are more likely to reinvest profit, if they reinvest at all, into other, equally small businesses rather than build up the first one. Tinker (1995) describes the diversification that these enterprises engage in as "amoebalike." For many micro-entrepreneurs, maintaining a steady income is a sufficient achievement; Eversole (2003, p. 109) describes those that make a very small but indispensible income as "subsistence businesses." Because of these characteristics and orientations, micro- and small-scale businesses are much more flexible than formal businesses, and these entrepreneurs can respond quickly to local market demands, sometimes appearing simply to fulfill this demand and then disappearing when demand dries up (EVERSOLE, 2003; TINKER, 1995).

Michael Blim (2005, p. 256) reminds us that, despite the blurring of lines between "big" capitalists and petty capitalists, "big business" still rules the world economy, even to the point of absorbing petty capitalism into its structure. Although Blim does not elaborate further, he does make the point that somewhere between home-based, piece-rate work and "true" entrepreneur- ship is a gray area of the informal economy, labeled by Bromley and Gerry (1979) as "disguised wage work." 'They define this as "when a firm regularly and directly appropriates part of the product of a person's work without that person legally being an employee" (BROMLEY; GERRY, 1979, p. 2). Although direct sales does not qualify as disguised wage work since companies are explicit about their reliance on a network of independent sales representatives, it is an example of the articulation between the aims and orientation of the distributors and the big businesses that rely on them. While the direct sales representatives in Ponta de Pedras operate like the petty capitalists described above, they are working within the structure of large companies driven principally by increasing profit margins.

\subsection{Direct sales companies in Ponta de Pedras}

This study focuses on only the three most important direct sales companies in Ponta de Pedras: Avon, Hermes, and Natura. Avon and Hermes have around two hundred direct sellers in the municipality, and women frequently work with both catalogs. Both companies have local coordinators in the town of Ponta de Pedras who receive and distribute product shipments, recruit new direct sellers, and help resolve any problems or issues a representative might have. Natura, on the other hand, does not have a local coordinator, so there is no way of knowing exactly how many representatives Natura has in Ponta de Pedras. Based on my observations, I estimate there are between fifteen and twenty. 
Avon and Natura are the two most sought after cosmetic and perfume brands in Ponta de Pedras; beauty products sold in stores, by informal vendors or other retailers cannot match Avon and Natura's popularity. Some shops sell cheap perfume, lipstick, mascara, and blush, but few people purchase them. In the next section I will describe each company and their basic operations, focusing on some of the hitches, the disjuncture between corporate expectations and how direct sales actually work.

\subsection{Avon}

In Brazil, Avon began in São Paulo and Rio de Janeiro with a limited line of seventy-five products advertised as developed "exclusively" for the Brazilian climate. In the 1970s, Avon expanded its sales networks to the Northeast region of Brazil, most likely in the cities of Recife and Salvador, and from there, into the Amazon estuary. While the historical development of Avon in the United States was characterized by an expansion from rural markets to suburban ones, in Brazil the company worked in reverse, beginning in urban areas and slowly spreading to rural regions.

Avon headquarters in Brazil are located in São Paulo, and the company claims to have over 1.1 million independent representatives in this country (AVON BRASIL, 2011). The hierarchy of Avon management, like most corporations, is based on regional divisions. Brazil is divided into five regions, which roughly correspond to the political regions of the country: The North, Northeast, CenterWest, Southeast, and South. ${ }^{3}$ Each region is comprised of numerous divisions, and each division is in turn comprised of sectors, the smallest official unit. The lowest level managers are in charge of sectors, and each sector manager may have between three and five "coordinators," in charge of smaller groups of Avon distributors in each sector. Although sector managers are Avon employees who receive a salary and benefits, coordinators, like distributors, are not directly employed by Avon. The coordinator is responsible for receiving and storing product shipments, and distributing products to the representatives, coordinating monthly meetings with the manager, and helping the sales force with any problems they may have with their orders or products. She is also responsible for encouraging distributors who have stopped selling to start again, and to collect payment from distributors who have fallen into debt with the company when they are more than three months behind on an order payment.

3 One main difference is that the state of Maranhão is a part of the North region, although politically it is considered to be a northeastern state. 
Avon produces approximately 24 catalog sets per calendar year. Each catalog set corresponds to a sales campaign, in which new products are introduced and different products are on sale. There are three catalogs for each campaign: 1) the main catalog, featuring makeup and other beauty products; 2) a secondary catalog called "Moda \& Casa" ("Fashion and Home"), which features other miscellaneous products such as clothes, purses, shoes, bedding, towels, books, CDs and DVDs, and 3) a catalog of discounted products meant only for distributors called Panorama. Representatives are constantly reminded not to show this catalog to their customers. Although many of the products in this catalog also appear in the main catalog, they are priced differently - typically 30 percent lower than the main catalog. The distributor can buy products from this catalog and sell them at a markup, usually the standard 30 percent commission Avon representatives earn on their sales. However, distributors are free to sell the products at any price they wish. If a distributor purchases a lipstick for $\mathrm{R} \$ 3.50$, she can sell it for $\mathrm{R} \$ 4.55, \mathrm{R} \$ 6.55$, or even $\mathrm{R} \$ 2.50$. The catalog is printed and distributed nationally, which means decisions concerning products that are offered in the catalog, special sales and promotions are also made at the national level. The Avon catalogs that distributors and customers receive in Ponta de Pedras are the exact same ones available in Recife, Minas Gerais, Rio de Janeiro, São Paulo, and Porto Alegre.

Sector divisions appear to be based on the density of Avon distributors in a given area. In Belém, one small neighborhood can be a sector in itself, and there are numerous sectors located within the city limits. The sector that includes Ponta de Pedras encompasses all of Marajó Island, a total of 13 different municipalities. Adriana is the sector manager for Marajó; at the time of fieldwork, she had been the manager for three years. I first met her in the summer of 2006, when she had held the job for only a few months. One of Adriana's biggest problems is traveling and transportation, and this is where the first disjuncture occurs in the chain of management between Avon headquarters in São Paulo and the Amazonian interior. She told me that her bosses do not understand the reality of doing business in Marajó. They question her travel expenses because they do not understand how expensive, and slow, it is to travel around an island that has little transportation. In order to get from one town in Marajó to another, one needs to travel first back to Belém and then catch a boat to the next location. Passenger boats to Marajó leave from Belém at best once a day, more often every other day. This means that she often has to spend a night in Belém in between visits to various communities on Marajó. Although by company policy Adriana is supposed to hold a meeting in each of the 12 municipalities on Marajó every month, she manages at most three or four meetings per year in Ponta de Pedras. In my eleven months of fieldwork, she held only one meeting. 
As mentioned above, direct sales companies rely on monthly meetings to instruct their otherwise untrained sales force in the corporate philosophy. Meetings are the principal source of the company's self-help rhetoric and inspiration toward greater sales and profits. I talked to Pamela, a sector manager in Ananindeua, on the outskirts of Belém's city limits. She told me that she tells potential recruits that Avon can help "build your dream" or "make your dream come true." Dreams in this case refer to the things a distributor would like to achieve in her life, such as to buy a house, a car, educate her children, pursue a hobby, and so on. She says that women do not usually want to sell Avon just because it is a fun thing to do. The goal is to make money, and not just enough money to get by, but ever increasing profits in order to fulfill her greatest material desires. If a distributor has a specific goal for her future profits, the reasoning goes, she will have greater motivation to sell more Avon products. This pitch for recruiting new distributors is a classic strategy in direct sales. Pamela works closely with her coordinators, so that when they recruit new distributors, they use the same technique of persuading women that they can finally achieve what they have always wanted by selling Avon.

I was able to interview one of the original five Avon distributors in Ponta de Pedras, Luisa, who recounted to me how Avon catalogs came to the municipality for the first time. In 1979, an Avon coordinator in Belém approached her and her husband about selling Avon in Ponta de Pedras. Luisa's husband, Raimundo, operated a passenger boat between Ponta de Pedras and Belém from 1975 to 2006, when he retired. Although Ponta de Pedras had a post office by 1979, it was still necessary to deliver the product orders to the manager in Belém every week. Luisa and the other four original Avon distributors sent their product orders through Raimundo on his boat, and he also delivered their product shipments. The number of Avon distributors in Ponta de Pedras grew rapidly, and in the mid-1980s, the manager in Belém appointed a local coordinator.

The current Avon coordinator is Margarita, who has held the position for the past sixteen years. The approach outlined by Pamela, the company line, is virtually unknown to Margarita. When I asked her about this approach to recruiting new distributors, and told her that another sector manager had told me about it, she had no idea what I was talking about; I had to explain to her the concept of selling Avon to build your dream. Margarita's relationship with Adriana is missing that vital transfer of official company scripts. Throughout the fieldwork, Margarita constantly complained about Adriana's unavailability; she was notoriously difficult to get a hold of on the phone, and never returned her calls. Adding these communication issues to her very infrequent visits to Ponta 
de Pedras results in a very fragile link between Avon corporate philosophy and Margarita's approach to managing her sales force.

In one of her rare meetings with distributors in Ponta de Pedras, Adriana emphasized the importance of using the Avon website to learn about products and place their orders. It is easy and convenient, she told a room of fifty distributors. Despite her three years of traveling around Marajó Island talking to local coordinators and distributors, Adriana is still unaware of the basic realities here: internet access is not easy or convenient for the majority of direct sales distributors. Most people in Ponta de Pedras have very little experience using a computer, much less the Internet. Unlike cell phones and television, computers have not yet made their way into rural Amazonian homes.

On the days that a product shipment arrives, Margarita's house is bustling with activity. Margarita supervises the unloading of the boxes, which then have to be counted and re-counted to ensure that the correct number of boxes have been delivered. Avon distributors hang out on the porch and around the house, waiting to receive their products. The distributors living in the interior, either in a riverine or upland community, have to plan their transportation so that they arrive in time to get their orders, and get back to their ride to go home again. Sometimes the boat leaves late or is unexpectedly held up because of weather. On days that the product shipment arrives later than planned, distributors often go home emptyhanded and come back another day. Because of the difficulties that women living in the interior have with getting to town, and the uncertainty of the exact time product deliveries arrive, Margarita often tells the distributors that the products will be arriving a day or two after the official date given to her by the manager.

\subsection{Natura}

Natura was founded in 1969 as a laboratory and small store in São Paulo. The company adopted the direct sales model in 1974 (NATURA, 2008). In the 1980s Natura established distribution centers and began operating in Argentina, followed by Chile, Peru and Bolivia. Natura recently opened retail stores in France, and in 2004, the company went public. Natura's business philosophy expresses a concern for environmental sustainability and producing high quality, natural cosmetic products. Natura features products and perfumes derived from Amazonian fruits and plants. Natura is generally recognized as having higher quality products than Avon, a perception reinforced by price differences between the two brands. The company claims to have around fifty million customers, fifty-six divisions and 850,000 distributors in Brazil alone (NATURA, 2008). 
Natura has 21-day campaigns called "cycles," and like Avon, issues a new catalog for each campaign featuring new products and new sales. Natura uses a point system to reward its distributors, so distributors think of their sales volume in terms of points rather than currency. Although the catalogs are printed and distributed nationally, there is at least one regional difference in the products offered. In selected areas of São Paulo state,Natura offers a line of health food items called "frutifera." This line includes cereal bars, shakes, juice mixes and teas. This is a pilot line of products that has not been released nationwide. I discovered this in March of 2008 when I traveled to Campinas, São Paulo. I took the opportunity to visit an urban center in the southeast to investigate what direct sales are like there. I discovered that Natura is running a pilot program in Campinas called "Casa Natura," a place where the sector managers hold meetings, and anyone can come to sample a wide variety of Natura products, including the frutifera health food. The space includes a computer bank where distributors can access the Natura website and place their orders online. I met and interviewed a Natura coordinator and sector manager in Campinas, and attended a Natura monthly meeting. In addition to the regular monthly meetings, Casa Natura provides information sessions and workshops for distributors pertaining to various aspects of Natura products and general well being. The Casa Natura activities calendar for July/August 2009 includes courses on public speaking, makeup application, skincare, feminine elegance, etiquette, stretching and relaxation, massage, facial gymnastics, and increasing social networks with men. By providing guidance and advice on personal well-being, self-presentation and social interaction, Casa Natura inserts the company more fully into distributors' life, commanding greater loyalty and personal investment.

Zoe was the first person in Ponta de Pedras to sell Natura; she began in 1994, and for several years she was the only Natura representative. She started working for her cousin who sold Natura in Belém, but her cousin only gave her ten percent commission on her sales, and did not pass down any of the promotional sales prices to her. After two years of working for her cousin, she called the Natura 0800 number and signed up to be an independent distributor. At that time there was no official Natura manager for Ponta de Pedras, so she was directed to register with a manager in Belém. Zoe became an extremely successful Natura distributor in Ponta de Pedras. Before she moved to Belém in 1999 with her husband, she had over one hundred customers. After Zoe moved, her younger sister Nina and her ex-sister-in-law, Sara, began working for her and inherited the clients she left behind.

The Natura manager now technically responsible for Ponta de Pedras lives in the city of Bacarena. To get to Bacarena one would have to travel first to Belém, 
and then take another four-hour boat ride, with no way to make a round-trip in the same day. Although Natura managers, like Avon managers, are supposed to conduct monthly meetings, she maintains no contact with Natura distributors in Ponta de Pedras. Some Natura representatives have tried to contact the manager by telephone, but none have succeeded in actually talking to her. This manager shows no interest in the representatives she is supposedly responsible for in Ponta de Pedras. Most of the Natura sellers in Ponta de Pedras either work informally for an official representative who lives in Belém (usually a relative), or they have registered to work with an address in Belém. This means that there are no Natura meetings held in Ponta de Pedras. Natura representatives who do travel to Belém rarely attend the meetings held there. Natura representatives miss out completely on the motivational talks and product information disseminated at these meetings, which the company insists are essential for distributors' success.

The lack of a resident coordinator and access to meetings translates into fewer Natura representatives, who enjoy more sales,rather than Avon's large sales force with relatively fewer sales per representative. There are far fewer Natura representatives than there are for either Hermes or Avon. While Avon and Hermes representatives average between ten and twenty regular customers, Natura representatives have fifty to seventy customers each. Yet Natura products are much more expensive than Avon. Natura's popularity lies in the brand's reputation for superior quality over Avon, especially their perfume lines. Perfume, cologne, and scented soaps are important in Ponta de Pedras, and Natura is perceived as the best. The brand sells itself, making up for the distributors' lack of product expertise and selling techniques.

Natura and Avon representatives have some flexibility for selling on credit, or with a down payment. These companies allow their representatives to make payments on their product orders up to fifteen days after the products have been shipped from São Paulo. Customers ideally pay for their purchases when the representative delivers them, and the representative sends her payment before the due date. This means that the representative can place an order for products and receive them before securing any payment from the customer. If a Natura or Avon representative does not send in her payment by the deadline, her account is charged a daily fine, and she is barred from placing any other orders until she pays the entire debt. If three months pass without any payment, both companies will send her name and information to the National Credit Protection Services (SPC). When this happens, the person cannot take out any bank loans, credit cards, or receive federal assistance for agricultural or agro-forestry activities until the debt is paid. 


\subsection{Hermes}

Hermes is a direct sales company very different from Avon and Natura. Rather than beauty products, Hermes primarily offers cheap household goods: kitchen utensils, plastic containers, clothing, shoes, and other miscellaneous products. Customers do not buy Hermes products because of a brand reputation for quality; cheap prices and the convenience of catalog purchases are the main customer appeal. Hermes was founded in 1942 in Rio de Janeiro, the location of its headquarters today. While the company employs roughly fifteen hundred salaried employees, it boasts on its website around forty-five hundred franchises with five hundred thousand distributors, or "consultants" (HERMES S.A., 2009). The Hermes website also claims that, with over ten million customers, it is the largest Brazilian catalog sales company de variedades, (of variety goods).

Hermes has a slightly different structure than both Natura and Avon. Rather than a hierarchy of managers in charge of sectors, divisions, and regions, the company maintains regional offices that recruit franchise coordinators who in turn recruit distributors and manage product orders and shipments. Hermes is not ascharismatic in the Weberian sense as other direct sales corporations, in that they invest much less in motivational tools and salaried, local managers who run monthly meetings. Hermes also issues fewer catalogs per year, choosing instead to have multiple "campaigns" per catalog. This means that a distributor has three or four opportunities to send in orders using the same catalog before it is no longer valid. This method is more appropriate for a company that does not feature new sales and new products every fifteen or twenty-one days, cuts down on the costs of printing and distributing new catalogs, and means that distributors have a longer period to collect orders on the same catalog - they have more breathing room, as some distributors put it. However, unlike Avon and Nature representatives who earn 30 percent commission on their sales, Hermes distributors only earn 20 percent commission on their sales.

Also unlike Natura and Avon, Hermes representatives are required to pay for their orders at the time of placing the order, before they receive the product shipments. Therefore, they generally need to collect payment from customers before delivering their purchases. This system is less risky for the representative, in that requiring payment ahead of time assures that they will not fall into debt with the company, as can happen, and frequently does, with Avon and Natura. However, consumers in Ponta de Pedras often prefer to pay only upon receiving their purchases, or even a long time afterwards; they view the Hermes requirements as restrictive. Some Hermes representatives who have the means will pay for some 
of their orders out of pocket - even borrow money from their husbands or other relatives - and allow trusted customers to pay them after the products are delivered.

In Ponta de Pedras, the Hermes coordinator, Evelyn, operates out of a small store on a road parallel with the Marajó-Açu River, three streets back. Evelyn is the wife of the post office manager, and they are one of the local elite, conservative families. Several years ago, when Evelyn first started the Hermes franchise, she used the post office to run her business, recruiting distributors and arranging order pickups and drop offs. Even today residents of Ponta de Pedras refer to Hermes as o correio, the post office. Although she is the official Hermes coordinator, Evelyn has passed down the day-to-day duties of running the franchise to one of her daughters, Elena. Evelyn is also the director of one of the state grade schools in town. Because of Evelyn and Elena's social standing, and the strict way in which they conduct their business, many distributors say that they prefer to work with Margarita, who is much more accessible, identifies with them, and helps them out if they are a little short on their payments. Ironically, the direct sales company designed to be the most amenable to the realities of rural interior towns is rendered less accessible by the local coordinator.

\section{THE DIRECT SALES DISTRIBUTORS}

\subsection{Distributors' motives: "A cool thing" versus dreams}

There are three main reasons that all distributors, regardless of socioeconomic status, age, or place of residence, gave for going into direct sales: 1) independent source of income; 2) the ability to buy products at a discount; and 3) because direct sales is "a cool thing to do" ("é legal"). In the survey, the distributors who said that they wanted their own source of income most often responded that they use their profit to either help pay for food and bills, or to buy personal items for themselves and/or their children. Those who sell in order to buy products often try to get just enough orders from customers to cover the cost of the products they want for themselves. This is similar to using the profit to pay for personal items; the difference lies in the distributors' approach to selling. The third motive, however, appears more ambiguous. Many distributors said, "I saw other people doing it, and I became curious, I wanted to try it out," or "I wanted something to do, and it looked like fun." In this context, the women employing the phrase é legal ("it's cool") to describe their attraction to direct sales are also implying that this kind of work is an opportunity for them to participate in an organization in 
which they not only feel a sense of community and belonging, but a great interest in the products and world of beauty that make up direct sales.

This widespread curiosity directly contradicts what Pamela, the Avon sector manager, had told me, that no one wants to sell Avon just to sell Avon. In Ponta de Pedras, at least, that is exactly what women want to do: look at the colorful catalogs and explore the world of beauty and domestic products. Selling Avon, Natura, and Hermes also provides a reason for socializing with their friends and neighbors. Masae Yuasa (2006), studying Japanese housewives working for an MLM company, Maple, emphasizes the role of direct sales in women's social lives. Housewives' lives are defined by the chores and tasks they perform in the home and in the community for others: getting the children to school, preparing meals, attending community service meetings, and so on. Their time is organized around concrete tasks, and indeed many women said that they liked working for Maple because they are able to work while attending to their everyday responsibilities.

Most women have difficulty saying how much time they actually spend working because it is so embedded and intertwined with other activities. This is what Yuasa, citing Edward Hall (1983), describes as P-time, or polychronic time, which "respects people and relationships more than the schedule" (2006, p. 215) In contrast, M-time, or mono-chronic time, "schedules events as separate items...the schedule commands and dominates people" (YUASA, 2006, p. 226). Yuasa states that M-time is "male time"; it dominates the world of work and modern time consciousness, in which concrete plans for the future are made, and transform the present. Maple distributors do not work in this modern time consciousness, and do not have requisite experiences of "accomplishing their own aims by self-planning and self-discipline” (YUASA, 2006, p. 226). Her main argument is that women's experience of P-time limits their chances for entrepreneurial success. Furthermore, these Japanese housewives-distributors care more about the opportunities to socialize and have meaningful relationships with other women than about meeting their sales goals (YUASA, 2006, p. 215). The sociality aspect of direct sales is a double-edged sword for the corporations. They want to harness these relationships for profit, but the tendency for sales calls to turn into social hour distracts both customer and distributor from the business of selling and buying products. The idea of "building your dreams with Avon," as explained by Pamela, is also a subtle attempt to steer distributors toward less chit chat, more sales calls, and more profits.

There is an important difference between Yuasa's Japanese housewives and the distributors I talked to in Ponta de Pedras. Yuasa describes the profit from their work as negligible, and the products as unfashionable and frumpy that 
customers nevertheless "seem to tolerate" (2006, p. 217); the major incentive for women to work with this company is the opportunity to socialize and connect with other women, not the products. In Ponta de Pedras, however, selling is not just about socializing; the catalogs and products themselves are a major attraction. Distributors who said direct sales looked like a "cool thing" as their motive for doing it are referring not only to the opportunity to socialize, but the opportunity to participate in another world through the catalogs, and participate in that world by purchasing the products. In the absence of corporate messages constantly reminding them to always increase their sales, distributors use their work not to "realize a dream" fueled by profits, but to pay their household bills and buy discounted personal items for themselves and their children. In Chapter 5 I will explore in greater detail the relationships distributors and customers alike have with the catalogs and products offered through direct sales; the remainder of this chapter focuses on the act of selling and the nature of the social relationships that develop around - and are sometimes destroyed by - direct sales.

\subsection{Selling}

When talking about selling, distributors often refer to one of two types: the literal act of selling a product to a customer, and "selling" as persuasion, being a good talker and convincing otherwise unsure customers to commit to a sale. Margarita made the most explicit reference to these different kinds of selling during the focus group I conducted in January 2009:

Margarita: Olha, mana! I'll tell the truth, I am not a good revendedora. I don't know how to sell. I've already told you this, right? ...The way to do it is like this, to say [to the customer], "let me tell you about this product..." I don't have that way of selling, you know? Not like Nina, she has it, right? ...

$J C$ : But didn't you tell me that you almost always have the highest sales? ${ }^{4}$

Margarita: No, I do sell. But not that kind of selling, the kind I think is cool. To arrive at the door, talk smoothly, introduce yourself, introduce the product, like that, you know? I sell, yes, but I don't have... that way with it.

Five direct sales distributors participated in the focus group: Margarita, the Avon coordinator; Nina, one of the most successful Natura distributors; Dora, an Avon distributor who is starting to pass her customers to her daughter; Raquel, who sells both Hermes and Avon and lives in a nearby riverine community; and Juliane, an Hermes distributor. Joana, my research assistant, was also present to

\footnotetext{
I later learned that Margarita has the highest sales volume because she places orders for a few other women under her name, women who have gone into debt with the company and cannot place orders themselves.
} 
help moderate the discussion. All of the participants except for Nina claimed not to be very good sellers themselves. Nina is widely recognized as one of the best, but she was not always the smooth-talking saleswoman and the assertive payment collector she is today. She explained to me that she was shy at first, and embarrassed to repeatedly ask customers for the money they owed her. She told me that her sister, Zoe, taught her how to sell products and "get the money." "I didn't know how to talk to people, how to sell... and I didn't know how to collect."

When Zoe moved to Belém she enrolled in college and graduated with a degree in business management. She worked as an intern for Natura while in school, and after graduating she accepted a position at the same Natura office in Belém. She worked there for two years, until December of 2008 when the company closed the office and moved it to Brasilia. When Zoe left Ponta de Pedras, she had built up a large base of loyal customers. She passed on her customers to Nina and her ex-sister-in-law, Sara. They both continue to sell under Zoe's name; they are not officially registered as Natura distributors themselves. Zoe lets them keep the 30 percent commission on their sales, and their contribution to Zoe's sales numbers earns her recognition, prizes and awards from the company. Her education, internship and employment with Natura in Belém help explain her dedication and her impressive knowledge of sales techniques and of the products. She passed on this knowledge to Nina, who gradually modeled herself after her sister. The fact that she is working under Zoe's name is an added incentive for her to collect her payments. She said, "There is so much pressure... because I sell for her [Zoe], not for myself. I learned to be firm, to be hard, because I can say to people, 'these are my sister's products, in my sister's name, it's not just for me.' "

When I asked the focus groups whatare the essential qualitiesin order achieve success in this line of work, they responded that being a good talker and knowing the products are most important. The participants agreed that it helps greatly if the seller likes to read, since it is necessary to read the company literature to know the products and talk about them to customers. However, very few direct sales distributors said that they gave the product literature much attention when it arrives with their orders. While many study the catalog itself, especially to learn what products are on special offer, they do not read corporate literature such as the advice articles in the Panorama catalog.

The majority of distributors do very little selling of the persuading type; most let the catalogs do the selling. In some cases, particularly among those who live in the interior, the distributor barely even speaks to her customers. Several Avon representatives who live in Jagarajó and Rio Fortaleza told me that they simply 
drop off the catalog at a customer's house, let the customer mark the products she wants, and then pick it up the next day. Most often, a distributor will simply inform the customer about the newest perfume to come out and which products are on sale, and then leave the customer to peruse the catalog on her own time. The sales calls that I witnessed were just as likely to be awkward encounters as they were social visits among friends.

\subsection{Selling on credit}

With the widely accepted practice of selling on credit in Ponta de Pedras, the local concept of "selling" is an act completely separate from collecting payment. As one participant put it: "Selling is easy; collecting [payment] is much harder." Other distributors define the difference between selling a product and receiving payment for the same product as a difference in attitude on the part of the customer: "she [the customer] buys happily, but she is not happy when it's time to pay. She is annoyed when it's time to pay."

Selling on credit throughout the Amazon can be traced back to the aviamento system, as well as other institutional relationships that have been cultural features of this region long before Avon arrived in 1978. Aviamento describes the system of exchanging rubber, timber, and other drogas de sertão from the region: rubbertappers traded the rubber they collected and processed in exchange for credit with the landowner or at the local trading post. Trading posts sold the rubber to regional merchants traveling up and down the rivers; these merchants in turn sold the rubber and other forest goods to larger companies, until the goods ended up in the hands of national and international corporations. At the bottom of the pyramid, the rubber-tappers and extractors were sharecroppers and slaves, held perpetually in debt servitude to the trading post and/or landowner, as the value of the rubber and other forest goods never amounted to the exorbitant prices of the goods, medicine, and tools essential for maintaining the household. Although aviamento is no longer in place, its legacy remains in the impact the system had on the infrastructure of water transportation and social relationships.

In his discussion of social relations and social classes in Gurupá, Charles Wagley (1976) explained that elite families have a charge account at Casa Gato, one of four supermarkets. Typically these families rarely pay up their account, despite having a regular salary. The clerks at Casa Gato always encourage them to make additional purchases, since it is good to have a customer with a regular income to remain in debt, and therefore feel obliged to continue purchasing from the same debtor (WAGLEY, 1973, p. 116). Poor families were not encouraged 
to make additional purchases, although they are extended credit at the store also, with greater reluctance (WAGLEY, 1973, p. 117-118).

Credit functions in much the same way in Ponta de Pedras today, over sixty years after Wagley conducted his study in Gurupá. The biggest change over this time has been the increase in consumer goods available and the number of stores and small shops. In the past three or four years two of the biggest supermarkets in Ponta de Pedras, Marajó Supercenter and Barsileirinho, began accepting debit and credit cards. However, both stores continue to keep notebooks with hand written records of customers' debts. Customers who are late with their payments are considered a nuisance. Late payments may damage a relationship, but not irreparably. A customer who skips out on his or her payment altogether is a caloteiro, and if the lack of payment was intentional, the credit relationship is used up or destroyed. There is no formal or legal recourse for the vendor if a customer refuses to pay for a product he or she has taken on credit, and the repercussion for the customer is a bad reputation as a caloteiro.

In his introduction to The Social Life of Things, Appadurai argues that the act of exchange is what creates value in commodities; value is not an inherent property of objects, but a judgment made about them by the subject (Appadurai 1986:3). Following Simmel, Appadurai's analytical concept of regimes of value focuses on exchange, rather than production, as the act that imparts value unto objects. The value of any particular thing therefore depends upon the social context of the exchange and the social positions, desires, demands, and situations, of the individuals involved in the exchange; value is not an inherent property of anything (APPADURAI, 1986). In the Amazon, selling on credit is a long-standing cultural practice. Relationships are built through the extension of credit and the payment of debt, and therefore the products involved in these exchanges represent these relationships. When a customer consistently avoids a creditor or repeatedly gives excuses for not paying, the vendor decides whether to continue pursuing payment from the customer, or cut her losses and give up. When a customer skips out on payment, she generally tries to avoid running into the person she owes in public. Several distributors told me that "when a customer becomes a caloteira, the representative loses three things: the product, the money, and the relationship."

Women who work in direct sales in Ponta de Pedras are most often lower-class and poor women unaccustomed to exercising authority or exuding the confidence necessary for collecting payment from customers. Direct sales distributors do not have the clout that storeowners have, and are not rich patrons who give away money and gifts to maintain their status. Not giving credit is simply not an option. Margarita told me: "If she [the distributor] doesn't sell on credit, 
she's not going to sell anything. All of her products will stay with her." Storeowners and direct sales distributors alike are expected to sell on credit, but distributors are more vulnerable to the financial harm caused by slow payers and caloteiros. Most storeowners have a client base that is larger than the average direct sales distributor, who has approximately ten regular customers. Customers also tend to make purchases more frequently in stores than they do with direct sales representatives. Storefronts require investment capital, both for the physical building and stock inventory. A larger customer base that makes more frequent purchases, as well as start-up investment, mean that most storeowners are better able to extend credit and still make some profit, or at least break even, when some of them are slow payers. Direct sales distributors, even those who work with a stock of products ordered from the Panorama catalog, do not have the same kind of stability.

Direct sales distributors who are poor and do not have much capital to invest in their business often avoid customers who place large orders; customers who owe only a small amount of money are more likely to pay than those who owe a large sum. Most distributors also try to avoid customers who do not have a steady income, especially during the off-season. They seek out customers among those they know that have a steady income through government employment or benefits. Many representatives take advantage of their patron-client relationships with politicians and members of the local elite. Diane, the wife of the only PT city councilman mentioned in Chapter 2, regularly buys products from four different distributors, but she will buy products from almost any distributor who comes to her door:

Sometimes I end up buying something when I don't really want to. The revendedora shows up at my door, and I know she needs money... maybe her husband doesn't have a job now that the açaí season is over. I don't want to disappoint the revendedora, I want to stay on good terms with her.

I asked her if she had the option of buying the same products from a store rather than from a distributor, she answered that she would still buy from the distributors because she knows they need the money.

\subsection{The art of collecting money}

One day I sat outside and talked with Nina as she ironed clothes. I asked her to tell me about her method for collecting payment from her customers. She answered:

There are different kinds of people, and how I approach them depends on their personalities. Some people don't like it when you show up to their house and ask for the money they owe. So I go over and talk with that person, make conversation, and give her the chance to say, 'oh, by the way, here is the money I owe you...' 
but if she doesn't mention the money after awhile, I ask about it. Some people see me approaching and they go directly to get the money they owe me without saying anything. But some people try to hide. If I approach a house and the mother answers and says so-and-so isn't there, I will sit down and chat with the mother, wait out the daughter, see if she appears.

As a successful Natura distributor and hair stylist, Nina does not always have time to go out collecting payments, so she pays a cobradora (collector) a small fee to make visits for her from time to time. She is working with a new cobradorabecause the one she used before, Fiona, was not good at her job. Nina said she did not know how to pressure people to give her the money they owe. Later, when Fiona began to sell Natura for herself, Nina said she became a "harder" person; she began to understand the pressure of needing to pay for her orders. When Nina would send Fiona out to collect payments, she would come back with very little money. Nina would say to her, "why could you only get so little?" And Fiona would respond that she could not do anything, if they refuse to give her the money, she could not put her hands in their pockets and take it. But Nina argued that she could do something; she said, "you have to pressure people, and say things like, 'this is the last payment date, and you told me you would have this money for me, and I really need it, I can't wait any longer.' When you talk to people like that, they will say, 'Ok then, I'll pay you now, and pay the other guy [some other creditor] later. And now I'm done, I'm free of you.' " Nina said that people often have that kind of attitude, which is fine; but you have to be firm. In contrast, Fiona would simply do is ask for the money, and when the customer said no, she would accept it.

A customer who puts off paying and avoids her creditors is not necessarily a customer who will never pay, but the distributorhas to be persistent. Nina explained:

No one will ever voluntarily hand you the money they owe you. It is the seller's job to chase them down. If they can't pay the day you visit them, you find out when they're getting paid, and you be the first person to knock on their door, because most people have a lot of debts...if you get to their door too late, even on pay day, they will say they have no money left. Then you have no choice but to wait until next payday, and try again.

The poor in Ponta de Pedras often live on a precarious edge,where one strike of bad luck means they are unable to make a payment they previously counted on making. Although I heard stories of malicious customers who bought products on credit with no intention of ever paying for them, most distributors believe that the majority of customers who fail to pay do not do so purposefully. Some insisted to me that those who fail to pay are not very poor; they are customers who earn enough money to live comfortably, but do not know how to budget their money. 
Most distributors give up on collecting payment from a customer after two or three visits. These distributors say that they are embarrassed to repeatedly ask a customer for the money she owes. They would rather abandon the money rather than risk being perceived as a person who hounds customers. The pushy creditor is selfish and unconcerned about their customers' plight. Even when it is clear that the customer is the one who is acting selfishly and taking advantage of the vendor's credit, if the customer claims he or she is unable to make the payment, social etiquette dictates that the vendor should wait. If a creditor comes across as too pushy, customers become angry. They may finally make the payment, but in these cases the exchange relationship is also damaged, and customers will not purchase a second time from an overeager distributor.

While Nina has managed to overcome her embarrassment by learning how to read people and treat them accordingly, most representatives have not acquired her skills. However, Nina's talent is not the sole source of her success; her social standing in Ponta de Pedras is an important factor. Nina and Zoe come from a well-respected family; their great-uncle was one of the most popular mayors in recent history. Her immediate family is not rich, but neither are they poor, and her connections to wealthier, extended family means she is able to assume a more authoritative position vis-à-vis ordinary customers. ${ }^{5}$ Nina knows how to press people for their payments, and when to do it, all while retaining the loyalty of her customers.

Many distributors complained that some of their customers do not take them seriously. "They think that it's not really a job, selling Avon; but it is a job, just like any other," said Dora during the focus group session. "I told one customer, who kept putting me off, I said, 'Look, you have to pay me, because I have to pay for my boxes, and we have to pay fines if we're late.' And she responded, 'you pay fines?' And I showed her the invoice. She thought we didn't have to pay anything."

Selling on credit initially emerged as a fundamentally unequal exchange relationship: wealthier trading post owner and storeowners extended credit to the poor laborer/extractivist. Elite families were always given the most generous lines of credit, but credit is essential for the poor as well - they otherwise have no way to pay. In direct sales, many women are assuming the position of vendor and creditor for the first time, and are unaccustomed to it; they feel uneasy in this position. Some distributors who are uncomfortable at first learn over time how to manage the exchange relationships they enter into as direct sales distributors, but many do not. The biggest reason women gave for quitting direct sales was

5 The family's social position also explains Zoe's ability to attend college in Belém and work for Natura, which would be a very unusual achievement for most Pontapedrenses. 
debt; they were unable to collect payment from customers, and ended up owing Avon or Natura and having their name sent to the SPC.

\section{CONCLUSION}

What should a distributor do, according to the direct sales companies, if a customer is slow to pay? What are the best techniques for pursuing payment without annoying your customers? None of the Natura or Avon literature I came across even touches the subject of collecting payment; the standard assumption is that the customer pays upon delivery of the product. Yet the widespread practice of selling on credit, a culturally specific mode of exchange that Avon and Natura perhaps did not anticipate, is the reason why anyone in Ponta de Pedras can buy these brands in the first place.

During fieldwork, Margarita told me on several occasions that she wanted to just quit; being the Avon coordinator was too much work for too little pay. When Margarita said this, I asked what kept her from quitting. She told me, "Whenever I think about it, I think about the revendedoras (distributors) that depend on this work, they depend on me. It means so much to them, they really need it, especially the revendedoras who live in the interior. I can't quit because of them." Margarita says that she has remained the Avon coordinator for this long because she cares so much about the distributors who depend on her. She does not believe that someone else could do as well as she does. At the same time, she receives no recognition for her hard work from the company. Instead, she receives a bi-monthly reminder in the Avon reports that she has not met her sales goals. Margarita feels Avon has repeatedly let her down when, from her perspective, she has dedicated so many years to keeping things running smoothly for the distributors in Ponta de Pedras. But I believe there is another reason that keepsMargarita from quitting. She loves Avon, and she loves Avon products. She likes being in charge, receiving the shipments, and organizing the distributors; she is the center of attention. As the coordinator she gets a small box of free samples with most of the shipments. The products, and her relationships with customers and the distributors are important reasonsfor staying on as Avon coordinator.

While direct sales companies emphasize that becoming a representative requires no special skills, training, or education, once a person signs up for the job, the company attempts to mold each direct seller into the motivated, productive salesperson with a "go-getter" attitude who works hard to increase her sales. Yet the same flexibility that allows direct sales companies to exploit individual sellers' 
social networks also limits the extent to which these companies can influence the performance of their representatives. Given the nature of exchange relationships and credit in Ponta de Pedras, representatives' definition of "success" does not match corporate measures based on sales volume. For them, success is the ability to continually sell products without falling into debt, managing their customers in such a way that they can help out with household expenses or even buy a few products for themselves.

\section{REFERÊNCIAS}

ANNIS, S. God and Production in a Guatemalan Town. Austin: University of Texas Press, 1987.

APPADURAI, A. Introduction: Commodities and the Politics of Value. In: APPADURAI, A. (Org.). The Social Life of Things: Commodities in Cultural Perspective. Cambridge: Cambridge University Press, 1986. p. 3-63.

AVON Products Inc. Celebrating Women: Avon 125 Years. Documento electrônico, http:/ /www.avoncompany.com/aboutavon/timeline/pdf/ AvonInteractive'Timeline.pdf. 2011. Accessed: Febr. 28, 2011.

AVON Brasil. Quem Somos: A empresa. Documento electrónic, http:/ /www. br.avon.com/PRSuite/whoweare_main.page. 2011. Accessed: Apr. 8, 2011.

BARAHONA, I. V. Women's Micro and Small-Scale Enterprises' Emergence, Features and Limits: A Costa Rican Experience. In: DIGNARD, L.; HAVET, J. (Orgs.) Women in Micro-and Small-Scale Enterprise Development. Boulder: Westview Press, p. 145-157, 1995.

BIGGART, N. W. Charismatic Capitalism: Direct Selling Organizations in America. Chicago; London: University of Chicago Press, 1989.

BROMLEY, R.; GERRY, C. (Orgs.). Casual Work and Poverty in Third World Cities. New York: Wiley, 1979.

BLIM, M. Capitalisms in Late Modernity. Annual Review of Anthropology, v. 29, p. 2-38, 2000.

EVERSOLE, R. My Business Pays Me: Labourers and Entrepreneurs Among the Self-Employed Poor in Latin America. Bulletin of Latin American Research, v. 22, n.1, p. 102-116, 2003. 
GUDEMAN, S. Remodeling the House of Economics: Culture and Innnovation. American Ethnologist, v. 19, n. 1, p. 141-154, 1992.

HALL, E. The Dance of Life: The Other Dimension of Time. New York: Anchor Books, 1983.

HERMES S. A. Hermes, Venda Direta.Documento electrônico, https://www. hermes.com.br/ franquia.asp? Link=VD\&cd_sitecliente=0, 2009. Accessed: Oct. 5,2010 .

HIMMELWEIT, S. Introduction: From Labour to Care. In: HIMMELWEIT, S. (Org.). Inside the Household: From Labour to Care. New York: St. Martin's Press, 2000. p. xv-xxxiii.

MANKO, K. Ding Dong, Avon Calling! Gender, Business, and Door-toDoor Selling, 1890-1955. 2001. Tese (Doutorado em História) - University of Delaware, Newark, 2001.

NATURA Cosméticos. Relatório anual. Documento electrônico: <http:// natura.infoinvest.com.br/ptb/3536/relatorio20anual202008_ versao20completa20revista_0906_FINAL.pdf, 2008>. Accessed: Mar. 27, 2010.

TINKER, I. The Human Economy of Micro-Entrepreneurs. In: DIGNARD, L.; HAVET, J. (Orgs.). Women in Micro-and Small-Scale Enterprise Development. Boulder: Westview Press, 1995. p. 25-39.

WAGLEY, C. Amazon Town: A Study of Man in the Tropics. Oxford: Oxford University Press, 1973.

WILSON, A. The Empire of Direct Sales and the Making of Thai Entrepreneurs. Critique of Anthropology, v. 19, n. 4, p. 401-422, 1999.

WORLD Federation of Direct Selling Associations. Supplied: <http://www. wfdsa.org/statistics/index.cfm?fa=display_stats\&number=1, 2010. Accessed: Apr. 8, 2011.

YUASA, M. Japanese Women in Management: Getting Closer to "Realities" in Japan. In: YUKONGDI, V.; BENSON, J. (Orgs.).Women in Asian Management. London; New York: Routledge, 2006. p. 56-72. 